\title{
Trypanosoma evansi (Kinetoplastida: Trypanosomatidae) in capybaras (Hydrochoerus hydrochaeris): prevalence, effect and sexual selection
}

\author{
Emilio A. Herrera ${ }^{1 *} \&$ Yarlenis Castro $^{2}$ \\ 1. Departamento de Estudios Ambientales, Universidad Simón Bolívar, Apdo. 89.000, Caracas 1080-A, Venezuela; \\ eherre@usb.ve \\ 2. Departamento de Biología Celular, Universidad Simón Bolívar, Apdo. 89.000, Caracas 1080-A, Venezuela; \\ liceyarlenis@gmail.com \\ * Correspondence
}

Received 27-VII-2015. C Corrected 08-II-2016. Accepted 11-III-2016.

\begin{abstract}
Parasites play a crucial role in the ecology of animals. They also appear to be important in mechanisms underlying sexual selection processes. In this article we study the prevalence, effect and potential role in sexual selection of the protozoon Trypanosoma evansi in capybaras, Hydrochoerus hydrochaeris. We collected our samples from the annual capybara cull of a ranch in Venezuela, using the volume of the snout scent gland as an indicator of dominance; the residuals of body weight as indicators of condition; and the residuals of the spleen mass as indicators of immune function. Overall prevalence was $30.9 \%(\mathrm{~N}=97)$ with no difference between males and females, and no relation between infection with $T$. evansi and condition. However, we found that infected animals had larger spleens (residuals), indicating an immunological cost of the infection. Furthermore, males with larger snout scent glands (more dominant) were less likely to be infected than males with smaller glands (less dominant), suggesting that by choosing males with a large glands, females may be using the gland as an indicator of health, which is consistent with the "good genes" view of sexual selection. Rev. Biol. Trop. 65 (1): 229-237. Epub 2017 March 01.
\end{abstract}

Key words: capybara, Hydrochoerus hydrochaeris, parasites, sexual selection, Trypanosoma evansi.

Parasites are important factors in the dynamics of their host's populations (Pedersen \& Greives, 2008) by affecting their survival, reproduction (Albon et al., 2002) and behavior (Berdoy, Webster, \& Macdonald, 2000). However, suspected parasites can often be commensals or even mutualistic symbionts (Ewald, 1987). Even when clear phenotypic effects of a parasitic infection are not apparent, an infection can carry a significant immunological cost (Lochmiller \& Deerenberg, 2000). Parasites have also been hypothesized as central role players in the process of sexual selection. Thus, Hamilton and Zuk (1982) have argued -and presented evidence- that it is advantageous for a male bird to advertise his lack of parasites by developing and showing off bright coloration in his plumage. Such a display, being costly, would be an honest signal of condition which females could use to choose good quality males (Grafen, 1990; Keyser \& Hill, 2000). In mammals, other features such as antlers or manes may play the same role as do colors in birds. In particular, the development of a scent gland and scent marking behavior may be subject to sexual selection (e.g. bats, Voigt et al., 2008; review by Penn \& Potts, 1998) and may function as honest signals of health (Zala, Potts, \& Penn, 2004).

Capybaras, Hydrochoerus hydrochaeris (Linnaeus, 1758), large (50 kg), grazing rodents, are common in the savannahs and wetlands of tropical and subtropical South America (Ojasti, 1973), where they live in stable social groups composed of both males and females, with an average of 3-4 male 
and 6-7 female adults per group (Herrera \& Macdonald, 1987; Herrera, Salas, Congdon, Corriale, \& Tang-Martínez, 2011). In these groups, a clear-cut and long-lasting dominance hierarchy is evident among the males: the dominant male is usually able to win all encounters against most subordinates, making the hierarchy strictly linear. Ranks in the hierarchy may last for three years or more (Herrera \& Macdonald, 1993). The dominant male obtains most matings, although subordinates do get a not-insignificant number of copulations (Herrera \& Macdonald, 1993). Dominant males tend to have the snout scent gland, or morrillo, significantly larger than subordinates (Herrera \& Macdonald, 1993) and solitary males, whose reproductive success is likely to be minimal, have smaller glands than stable group members (Salas, 1999). For this reason, this gland has been used in previous studies as an indicator of rank (Herrera, 1992; López, Muñoz, \& Herrera, 2008). Furthermore, because of its large size and conspicuousness in dominant males, Moreira, Macdonald and Clarke (1997) have suggested that the morrillo may act as a visual sign of dominance. The size of this gland also significantly correlates with testosterone titer in blood (Costa \& Paula, 2006).

Capybaras carry many species of intestinal helminths and blood parasites (Mones, 1982; Salas \& Herrera, 2004). Among the intestinal helminths, the intensities of infestation by Monoecocestus macrobursatum and Viannella hydrochoeri have been found to correlate negatively with the physical condition of the host, as assessed by the residuals of the body weight-body length regression (Salas \& Herrera, 2004). The effects of blood parasites, such as the protozoon Trypanosoma evansi, are little known. T. evansi is transmitted mechanically by biting flies of the Tabanidae family and there are reports that it causes a disease called "derrengadera", which appears to paralyze the hindquarters of capybaras, but this is rarely seen in the wild (Cueto, 2012; pers. obs.). Trypanosoma evansi is the etiological agent of equine trypanosomiasis, a disease known as "surra" or "mal de caderas" (Dequesnes, 2004) which can be fatal in horses. It also produces intense anemia in coatis, Nasua nasua (Herrera et al., 2002) although not in capybaras (Herrera et al., 2004), and can cause death in experimentally infected mice (Tejero, Arias-Mota, Roschmann-Gonzalez, Aso, \& Finol 2010). Capybaras have been named as reservoirs of $T$. evansi since they seem to be frequent carriers of this protozoon without apparent effects on their health (Morales, Wells, \& Angel, 1976).

In this paper, we present data on the prevalence and intensity of infection by Trypanosoma evansi in a population of capybaras and relate these variables to the physical state of the animals (using a condition index), their sex, and, in the case of females, their reproductive status (pregnant v. non-pregnant). We also evaluate the immunological cost of infection (see Methods). Finally, we test the value of the snout scent gland as an indicator of health, by relating its size to the incidence and intensity of infection, and to one aspect of the immune system (spleen size) and therefore as a potential mate choice cue for females.

\section{MATERIALS AND METHODS}

Field procedures: We sampled commercially harvested capybaras (Herrera \& Barreto, 2012) at Hato Santa Luisa (under a commercial culling permit issued to the ranch by the Wildlife Service of the Ministry of the Environment of Venezuela), a 22000 ha cattle ranch in the seasonally flooded savannahs (the Llanos) of Apure, Venezuela $\left(7^{\circ} 42^{\prime} 18^{\prime \prime} \mathrm{N}-67^{\circ} 26^{\prime} 41^{\prime}\right.$ ' W). In March 2009, we followed the workers as they culled the animals throughout the ranch. For each animal, we measured eviscerated body mass (nearest $\mathrm{kg}$ ), because it allowed a comparison of carcass mass without the variation caused by gut volume or reproductive status in females. Total body length (tip of the snout to tip of the tail -a stump-) was measured to the nearest $0.5 \mathrm{~cm}$. As a measure of condition we used the residuals of the regression equation between eviscerated body mass and total length. Because of the small range of sizes used (all animals were of adult 
size), the best-fit regression was linear. The height, length and width (nearest $\mathrm{mm}$ ) of the snout scent gland, the morrillo, were also measured. The shape of this gland is roughly that of half an ellipsoid (cut horizontally), so its volume was calculated by multiplying the three measures (this is not the actual volume of an ellipsoid but since using the geometric formula simply adds constant values -integers and $\Pi-$, the relative values are the same).

The spleen is an important organ of the immune system (Mebius \& Kraal, 2005), in particular because of its role at removing blood-borne microorganisms such as T. evansi, so its use in this study is especially relevant. In fact, there is evidence that a larger spleen in a healthy animal is an indicator of a competent immune system (Corbin et al., 2008; Vicente, Pérez-Rodríguez, \& Gortázar, 2007). For this reason, we used the weight of the spleen (nearest gram) to assess immunocompetence in healthy individuals, defined as animals negatively diagnosed with $T$. evansi.

But the spleen tends to swell in a sick animal as it helps fight parasites or other pathogens, as in Yankasa sheep (Audu, Esievo, Mohammed, \& Ajanusi, 1999) and Montane voles (Watkins, Moshier, Odell, \& Pinter, 1991). So, in infected animals, the amount of swelling of the spleen was used as an indicator of the cost in immune function associated with infection with $T$. evansi. In both cases (healthy and infected animals), we used the residuals of the regression of the spleen mass $\mathrm{v}$. body mass to control for the animal's size.

Age was estimated by collecting a humerus, removing all flesh, and recording the degree of ossification of proximal and distal epiphyses which ossify in a particular order in close relation with age (Ojasti, 1973). This was used to assign sampled individuals to adult age classes III (about 1 year old), IV (1.5-2.5 years old), V (2.5-5 years old), or VI (more than 5 years old), as described by Ojasti (1973) for wild capybaras in the same region.

Laboratory work: Immediately after death, a $5 \mathrm{~mL}$ blood sample was taken by cardiac puncture and collected in a tube with EDTA to prevent coagulation. Whole blood was preserved frozen. Once in the lab, DNA was extracted from each blood sample using an Axyprep blood genomic DNA miniprep kit (Axygen). To diagnose animals for T. evansi, we ran a PCR on whole blood DNA with $T$. evansi-specific primers ESAG6/7 (sequences, accession numbers and conditions in Fernández et al., 2009). PCR products were visualized in a $1.5 \%$ agarose gel, recording a positive whenever a band was visible at the expected size (237 base pairs). To confirm the identity of the amplified section of DNA, we sequenced the PCR products using MACROGEN Inc. commercial service and ran a BLAST (http://blast.ncbi.nlm.nih.gov/Blast. cgi) for nucleotide coincidence.

We compared prevalences using the Chisquare test of independence. Measures of weight and other normally distributed variables were analyzed using Student's T-test and Pearson correlation coefficient.

\section{RESULTS}

Prevalence: We sampled 105 animals and collected blood from 101 of them. Of all animals sampled, 97 could be unambiguously diagnosed for T. evansi and $30.9 \%$ were positive. From the sequences of the PCR products, we found a $98 \%$ maximum identity with $T$. evansi and T. brucei. Since T. brucei is an African species never recorded in Venezuela, or anywhere in South America, we are confident that our bands correspond to T. evansi.

Out of 40 females, $10(25 \%)$ were positive and of 57 males, 20 (35\%) were positive, with no significant difference in incidence of infection between genders $\left(\chi^{2}=1.12\right.$, d.f. $=1, \mathrm{P}=$ 0.290). The number of infected animals varied significantly with age, with a peak at age IV and diminishing thereafter (Fig. $1 ; \chi^{2}=14.5$, d.f. $=3, \mathrm{P}=0.002$ ).

Effect: There was no difference in body weight or condition index (C.I., residuals of the body mass-body length regression) between 


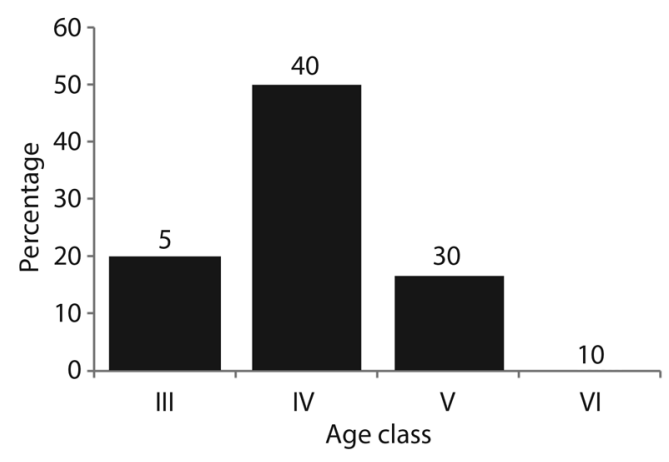

Fig. 1. Age and \% capybaras infected with Trypanosoma evansi at Hato Santa Luisa, Venezuela, 2009, for age classes III-VI. Numbers above bars are sample sizes.

negative and positive animals (body mass T-test: $\mathrm{t}=0.47$, d.f $=95, \mathrm{P}=0.637$; C.I.: $\mathrm{t}=1.27$, d.f. $=94, \mathrm{P}=0.208)$. Of 25 females checked for signs of pregnancy, 12 (48 \%) were noticeably pregnant and there was no association between reproductive state (pregnant v. non-pregnant) and incidence of $T$. evansi $\left(\chi^{2}=0.680\right.$, d.f. $=$ $1, \mathrm{P}=0.409)$. There was no difference in spleen mass or its residuals between males and females either overall or by infection status (uninfected or infected) and there was no correlation between spleen mass and body condition $(r=0.111$, d.f. $=95, P=0.280)$. The spleen was heavier, correcting for body mass (i.e., using the residuals), in infected individuals (mean residual $=+20.5$ ) than in non-infected ones $($ mean residual $=-9.4 ; \mathrm{t}=4.94$, d.f. $=92$, $\mathrm{P}<0.001$ ), suggesting that being infected with T. evansi imposes a significant immunological cost to the host.

Sexual selection: There was no correlation between spleen size and morrillo volume among the whole male sample $(\mathrm{r}=0.071, \mathrm{n}=$ $54, \mathrm{P}=0.608)$. However, among non-infected males, there was a near-significant correlation between morrillo volume and spleen mass $(\mathrm{r}=0.332, \mathrm{n}=33, \mathrm{P}=0.059$; Fig 2$)$, suggesting that healthy dominant males may have had a more competent immune system than healthy subordinates. In order to further test whether healthy (non-infected) large-morrillo males had larger spleens than healthy smallmorrillo males, two subsamples were taken: males with morrillos of more than $40 \mathrm{~cm}^{3}$ (hereafter called dominants) and those with morrillos with a volume smaller than $20 \mathrm{~cm}^{3}$ (subordinates or solitary males; the smallest morrillo was $2.6 \mathrm{~cm}^{3}$ and the largest 67.8 $\mathrm{cm}^{3}$ ). The mass of the spleen (residuals) of non-infected, dominant males $(-0.9 \pm 23.4)$

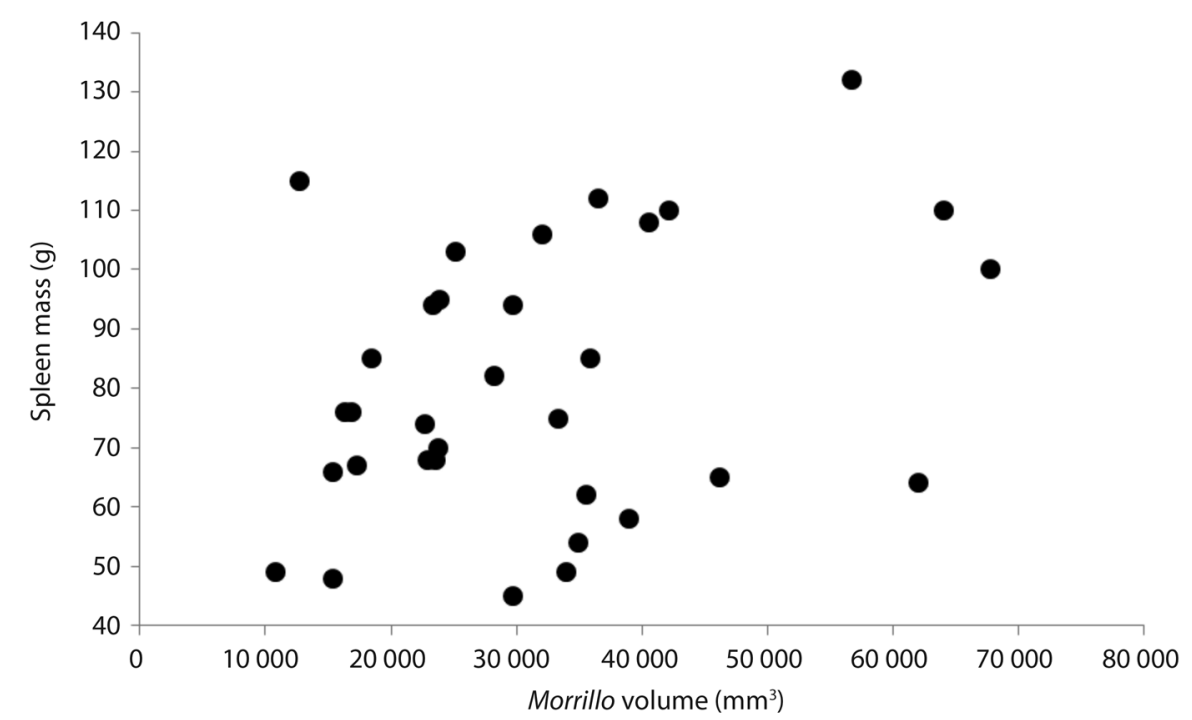

Fig. 2. Spleen mass in non-infected male capybaras as a function of the volume of the snout scent gland (the morrillo). Data from Hato Santa Luisa, Venezuela, 2009. 
was larger but not significantly so than that of non-infected subordinate males $(-11.5 \pm 23.1$; $\mathrm{t}=0.89$, d.f. $=13, \mathrm{P}=0.392$ ). Since the null hypothesis of the two preceding tests was the same, and the direction of the difference was also the same, we can use Fisher's combined probability method to assess the overall significance of these results (Sokal \& Rohlf, 1995). The trend was found to be significant $\left(\chi^{2}=7.78\right.$, d.f. $=2, \mathrm{P}<0.05)$. In other words, non-infected, dominant males had significantly larger spleens than non-infected, subordinate males.

The mean morrillo volume of non-infected males $\left(32.3 \pm 15.1 \mathrm{~cm}^{3}\right)$ was greater than that of infected males $\left(22.6 \pm 11.3 \mathrm{~cm}^{3} ; \mathrm{t}=2.43\right.$, d.f. $=52, \mathrm{P}=0.019$; Fig. 3), suggesting that healthier males were more dominant. Using the same subsamples of small morrillo and large morrillo males, we found that 1 of $9(11.1 \%)$ dominant males were infected, whereas 8 of 16 $(50 \%)$ subordinate males were infected, a significant difference $\left(\chi^{2}=4.35\right.$, d.f. $=1, \mathrm{P}=0.037$; Fig. 4). In summary, dominant male capybaras were generally less infected than subordinates.

\section{DISCUSSION}

Our sample had a prevalence of infection with T. evansi $(30.9 \%)$ similar to that of several previous studies of $T$. evansi infection

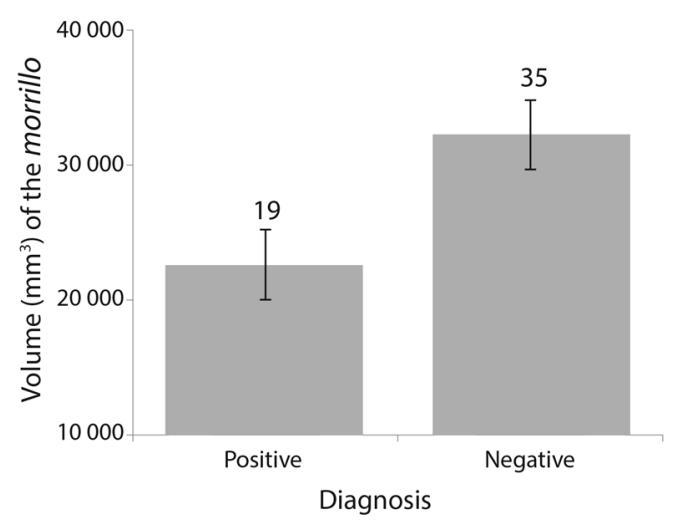

Fig. 3. Mean volume $\left(\mathrm{mm}^{3}\right)$ of the snout scent gland (the "morrillo") of male capybaras infected (positive) or not infected (negative) with Trypanosoma evansi at Hato Santa Luisa, Venezuela, in 2009. Numbers above bars are sample sizes. Bars are standard errors.

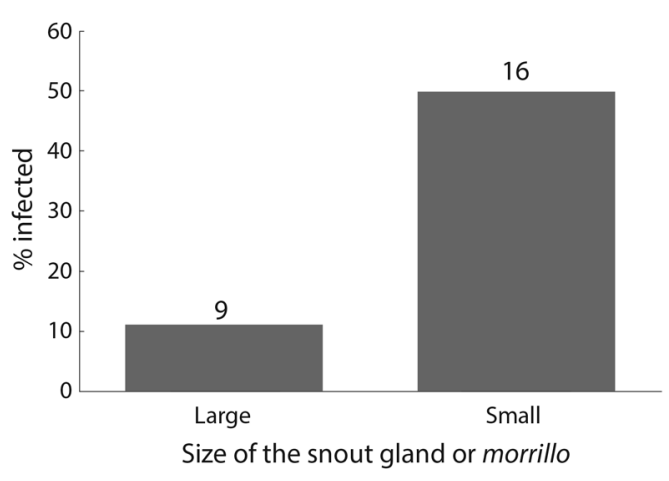

Fig. 4. Percentage capybara males infected with T. evansi, for two classes of males: those with large snout glands (morrillo volume greater than $40 \mathrm{~cm}^{3}$ ) or small morrillos (less than $20 \mathrm{~cm}^{3}$ ). Data from Hato Santa Luisa, Venezuela, 2009. Numbers above bars are sample sizes.

in capybaras, all carried out in the same general habitat as our study (Morales et al., 1976: $26.6 \%, \mathrm{~N}=33$; Nunes et al., 1993: $27 \% \mathrm{~N}=$ 22; García et al., 2003: $19.4 \%, \mathrm{~N}=186$ ), except one in which only $9 \%$ of the animals were infected (Arias, García, Rivera, \& López, 1997). The difference may be real, or due to the method used by the authors, which consisted of direct observation of the parasite in a blood smear on a microscope slide which tends to miss less intense infections (lower parasite titers). Our method of direct detection of $T$. evansi genes in a PCR is more sensitive and gives a more certain diagnosis. The prevalence we found is high, compared to T. evansi prevalences in other wild mammals from the Brazilian Pantanal (Herrera et al., 2005), a habitat similar to the Llanos: T. evansi prevalence in the Pantanal varied between 0 (Carnivora, most bats) and $20 \%$ (hematophagous bats, Desmodus rotundus) or $24.4 \%$ (peccaries, Tayassu pecari), but most were between 0 and $12 \%$ (Herrera et al., 2005). Since capybaras in the present study were sampled in a cattle ranch where horses (which are frequently infected with T. evansi; Herrera et al., 2004) abound, proximity to horses may have been a factor in the high prevalence we found.

We found significant differences in prevalence at different ages. Since the relation 
was not linear, i.e., it increases up to a certain age and then diminished, this is not easy to interpret. One could speculate that as the animals age the probability of infection is greater (more time, more chances), while the reduction of prevalence in the oldest animals may be related to the development of immunity, but we have no evidence for this.

In our study site, capybaras appeared to be tolerant to infection by $T$. evansi since no sign of debilitation was observed and rate of pregnancy was the same in infected and non infected females, confirming their suspected status as a reservoir (Morales et al., 1976). This is particularly notable since T. evansi is an old-world protozoon introduced into Venezuela in the early $19^{\text {th }}$ century from Spain (Canelón \& Meléndez, 2003). Whether there was strong selection when first exposed to the parasite, such that capybaras went through a bottleneck, or their immune system was able to resist the onslaught of this new pathogen, is unknown. Contrary to our results, a study by Nunes et al. (1993), carried out in similar habitat in Brazil, 13 of 24 infected capybaras $(n=53$ animals sampled) showed symptoms of "mal de cadeiras", i.e., difficulty in walking due to partial paralysis of hind limbs. The authors referred to both captive and wild capybaras but they did not specify whether the symptomatic animals were captive or wild.

Generally, males of wild mammals carry more parasites than females (e.g., Vicente et al., 2007; Hillegass, Waterman, \& Roth, 2008), possibly because they interact more, especially aggressively, as do male capybaras (Herrera \& Macdonald, 1993), but this was not the case in our study. The lack of a relation between frequency of aggression and probability of infection may be due to the fact that $T$. evansi is transmitted by a fly (mainly of the tabanid family; Dequesnes, 2004), so that transmission by direct contact in agonistic encounters is not a factor.

Mean spleen mass of infected animals was $34 \%$ greater than that of negative ones suggesting a significant immunological cost for this infection. Thus, although there was no obvious effect on general condition, infected animals appeared to need to mount a strong immune response to fight $T$. evansi. This is interesting since the general lack of external effects of infection with $T$. evansi seemed to indicate that capybaras did not suffer from such infection. Immunological costs of infection with blood parasites have been found in other mammals such as American mink (Neovison vison, Schulte-Hostedde \& Elsasser, 2011).

We found two lines of evidence suggesting that dominant males (those with larger morrillos) were healthier: (1) they had a lower prevalence of $T$. evansi infection and noninfected males had on average larger morrillos, a well-known indicator of dominance status (Herrera \& Macdonald, 1993; Salas, 1999); and (2) when not infected, they appeared to be better prepared to withstand infection since they had significantly larger spleens. These results then strongly suggest that animals higher in the hierarchy are healthier than those in the lower ranks. The reason for this is unclear. It may be due to a stronger immune system, as suggested by the finding that more dominant males had larger spleens. But an unrelated factor may be playing a role: subordinate males tend to be at the periphery of the group (Herrera \& Macdonald, 1993), and since flies fly in from around the group (there is obviously no way they disperse out from its center), the animals they first encounter would be subordinates. This would make subordinate males more likely to be bitten by potentially $T$. evansi-carrying flies. Whatever the mechanism (a more competent immune system or a lower probability of encountering an infected tabanid fly), dominant males do exhibit a lower prevalence of infection. Clearly, the reduced cost of fighting the infection would offer some reproductive advantage to males. Choosing a dominant male would afford benefits to the female only if the advantageous traits are heritable, since she does not receive direct benefits (such as protection or help raising her offspring) from her mating partner. Inheritance of dominance status is a complicated matter (Sartori \& Mantovani, 2013) but it has been shown to occur and to be under 
positive selection in red deer (Cervus elaphus; Wilson et al., 2011). The crucial factor here is the morrillo (and, presumably, the scent it produces), since it appears to be the only clue for the female when choosing a partner, and its size (and hence visibility; Moreira et al., 1997) does correlate with (potentially heritable) social and health advantages. So, if females choose males on the basis of the size of their scent gland, they will be selecting for healthy, socially dominant individuals, and these qualities can be passed on to her offspring. Since there is evidence that females actively avoid mating with subordinate males while preferring dominants (Bedoya, 2007), the mating tactic of female capybaras, based on using morrillo size as a proxy for mate quality, would be consistent with the "good-genes" view of sexual selection (e.g. Byers \& Waits, 2006).

A final point can be made regarding the correlation found in previous studies between volume of the morrillo and testosterone concentration in blood (Costa \& Paula, 2006). This correlation, in conjunction with the findings of this study that males with larger morrillos have larger spleens, i.e., a more competent immune system, is contrary to the so-called "immunocompentence handicap hypothesis" put forward by Folstad and Karter (1992). This hypothesis posits that a high concentration of testosterone imposes a cost to the male because it suppresses the immune system while enhancing secondary sexual characters (Folstad \& Karter, 1992), hence the paradox or handicap (Zahavi, 1975). Several studies have tested this hypothesis with mixed results (Roberts, Buchanan, \& Evans, 2004), and it clearly does not hold in the case of capybaras.

Further studies are necessary to determine the ontogeny of dominance and its heritability in capybaras, as well as more data on the relation between dominance, reproductive success, parasite load and female choice. This would improve our understanding of the effect of parasites on health, reproductive success and sexual selection not only in capybaras but in mammals in general.

\section{ACKNOWLEDGMENTS}

We would like to thank Carlos Rodríguez Matos for his generous hospitality in his ranch, as well as Reynaldo Alvarado and many Llaneros for their help with field work. We are most grateful to Ariana Gols and Solange Issa for their help at the ranch, and for their advice on various methodological issues. René Utrera kindly loaned his molecular genetics equipment to complete our analyses. Armando Reyna advised us on the molecular diagnostics methods of T. evansi. We thank Carlos Bosque and Solange Issa for their very useful comments on a previous draft of the manuscript. Also, excellent comments by one anonymous reviewer substantially improved our manuscript, and we are most grateful for this. We would like to express our gratitude to the Research Deanery (DID) at USB and Fonacit Venezuela (project 98003413) for financial support.

\section{RESUMEN}

Trypanosoma evansi (Kinetoplastida: Trypanosomatidae) en capibaras (Hydrochoerus hydrochaeris): prevalencia, efecto y selección sexual. Los parásitos juegan un papel crucial en la ecología de todos los animales. También parecen ser importantes en los mecanismos subyacentes a la selección sexual. En este artículo estudiamos la prevalencia, el efecto y el papel potencial en procesos de selección sexual del protozoario Trypanosoma evansi sobre el capibara (chigüire o carpincho), Hydrochoerus hydrochaeris. Recolectamos las muestras en una finca ganadera en Venezuela donde se lleva a cabo la matanza anual de capibaras para aprovechar su carne. Usamos el volumen de la glándula del hocico (el "morrillo") como indicador de dominancia; los residuales del peso como indicadores de condición física; y los residuales del peso del bazo como indicadores de la función inmunológica. La prevalencia total fue de $30.9 \%(\mathrm{~N}=97)$ y no encontramos diferencia entre machos y hembras ni tampoco detectamos correlación entre estado de infección y condición física. Sin embargo, encontramos que los animales infectados tenían el bazo inflamado, lo que indica un costo inmunológico de la infección. Además los machos con morrillos más grandes (más dominantes) tendían a estar menos infectados que los machos con morrillos más pequeños (subordinados), lo cual sugiere que al escoger machos con morrillos grandes, las hembras pueden estar escogiendo machos saludables, lo cual es consistente con la visión "buenos genes" de la selección sexual. 
Palabras clave: capibara, chigüire, carpincho, Hydrochoerus hydrochaeris, parásitos, selección sexual, Trypanosoma evansi.

\section{REFERENCES}

Albon, S. D., Stien A., Irvine, R. J., Langvatn, R., Ropstad, E., \& Halvorsen, O. (2002). The role of parasites in the dynamics of a reindeer population. Proceedings of the Royal Society of London Series B, 269, 1625-1632.

Arias, J. F., García, F., Rivera, M., \& López, R. (1997). Trypanosoma evansi in capybara from Venezuela. Journal of Wildlife Diseases, 33, 359-36.

Audu, P. A., Esievo, K. A., Mohammed, G., \& Ajanusi, O. J. (1999). Studies of infectivity and pathogenicity of an isolate of Trypanosoma evansi in Yankasa sheep. Veterniary Parasitology, 86, 185-190.

Bedoya, M. (2007). Elección de pareja en hembras de Hydrochoerus hydrochaeris (Tesis de Licenciatura). Universidad Simón Bolívar, Caracas, Venezuela.

Berdoy, M., Webster, J. P., \& Macdonald, D. W. (2000) Fatal attraction in rats infected with Toxoplasma gondii. Proceedings of the Royal Society of London Series B, 267, 1591-1594.

Byers, J. A., \& Waits, L. (2006). Good genes sexual selection in Nature. Proceedings of the National Academy of Sciences, 103, 16343-16345.

Canelón, J. L., \& Meléndez, R. D. (2003). Posible origen del Trypanosoma evansi en Venezuela. Veterinaria Tropical, 28, 155-167.

Corbin, E., Vicente, J., Martin-Hernando, M. P., Acevedo, P., Pérez-Rodríguez, L., \& Gortazar, C. (2008). Spleen mass as a measure of immune strength in mammals. Mammal Review, 38, 108-115.

Costa, D. S., \& Paula, T. A. R. (2006). Testosterone level, nasal gland volume and Leydig cell morphometry in capybaras (Hydrochoerus hydrochaeris). Arquivo Brasileiro de Medicina Veterinária e Zootecnia, $58,1086-1091$.

Cueto, G. (2012). Diseases of capybara. In J. R. Moreira, K. M. P. M. B. Ferraz, E. A. Herrera, \& Macdonald, D.W. (Eds.), Capybara: Biology, Use and Conservation of an Exceptional Neotropical Species (pp. 168-184). New York, USA: Springer.

Dequesnes, M. (2004). Livestock trypanosomoses and their vectors in Latin America. OIE (World Organisation for Animal Health).

Ewald, P. W. (1987). Transmission Modes and Evolution of the Parasitism-Mutualism Continuum. Annals of the New York Academy of Sciences, 503, 295-306.
Fernández, D., González-Baradat, B., Eleizalde, M., González-Marcano, E., Perrone, T., \& Mendoza, M. (2009). Trypanosoma evansi: A comparison of PCR and parasitological diagnostic tests in experimentally infected mice. Experimental Parasitology, 121, 1-7.

Folstad, I., \& Karter, A. J. (1992). Parasites, bright males and the immunocompetence handicap. American Naturalist, 139, 603-622.

García, H. A., García, M. E., Zerpa, H. A., Pérez, G., Contreras, C. E., Pivat, I. V., \& Mendoza-León, A. (2003). Detección parasitológica y molecular de infecciones naturales por Trypanosoma evansi y Trypanosoma vivax en búfalos de agua (Bubalus bubalis) y chigüires (Hydrochoerus hydrochaeris) en los estados Apure, Cojedes y Guárico, Venezuela. Revista de la Facultad de Ciencias Veterinarias de la Universidad Central de Venezuela, 44, 131-144.

Grafen, A. (1990). Biological signals as handicaps. Journal of Theoretical Biology, 144, 517-546.

Hamilton, W. D., \& Zuk, M. (1982). Heritable true fitness and bright birds: a role for parasites? Science, 218, 384-387.

Herrera, E. A. (1992). Size of testes and scent glands in capybaras, Hydrochaeris hydrochaeris (Rodentia: Caviomorpha). Journal of Mammalogy, 73, 871-875.

Herrera, E. A., \& Barreto, G. R. (2012). Capybaras as a source of protein: utilization and management in Venezuela. In J. R. Moreira, K. M. P. M. B. Ferraz, E. A. Herrera, \& D. W. Macdonald (Eds.), Capybara: Biology, use and conservation of an exceptional neotropical species (pp. 195-210). New York, USA: Springer.

Herrera, E. A., \& Macdonald, D. W. (1987). Group stability and the structure of a capybara population. Symposia of the Zoological Society of London, 58, 115-130.

Herrera, E. A., \& Macdonald, D. W. (1993). Aggression, dominance and mating success among capybara males. Behavioral Ecology, 4, 114-119.

Herrera, E. A., Salas, V., Congdon, E. R. C., Corriale, M. J., \& Tang-Martínez, Z. (2011). Capybara social structure and dispersal patterns: variations on a theme. Journal of Mammalogy, 92, 12-20.

Herrera, H. M., Alessi, A. C., Marques, L. C., Santana, A. E., Aquino, L. P. C. T., Menezes, R. F., Moraes, M. A. V., \& Machado, R. Z. (2002). Experimental Trypanosoma evansi infection in South American coati (Nasua nasua): hematological, biochemical and histopathological changes. Acta Tropica, 8, 203-210.

Herrera, H. M., Dávila, A. M. R., Norek, A., Abreu, U. G., Souza, S. S., D'Andrea, P. S., \& Jansen, A. M. (2004). Enzootiology of Trypanosoma evansi in Pantanal, Brazil. Veterinary Parasitology, 125, 263-275. 
Herrera, H. M., Norek, A., Freitas, T. P., Rademaker, V., Fernandes, O., \& Jansen, A. M. (2005). Domestic and wild mammals infection by Trypanosoma evansi in a pristine area of the Brazilian Pantanal region. Parasitology Research, 96, 121-126.

Hillegass, M. A., Waterman, J. M., \& Roth, J. D. (2008). The influence of sex and sociality on parasite loads in an African ground squirrel. Behavioral Ecology, 19, 1006-1011.

Keyser, A. J., \& Hill, G. E. (2000). Structurally based plumage coloration is an honest signal of condition. Behavioral Ecology, 11, 202-209.

Lochmiller, R. L., \& Deerenberg, C. (2000). Trade-offs in evolutionary immunology: just what is the cost of immunity? Oikos, 88, 87-98.

López, M., Muñoz, M. G., \& Herrera, E. A. (2008). Reproductive morphology of capybaras, Hydrochoerus hydrochaeris (Rodentia: Hystricognathi): no evidence for sperm competition? Mammalian Biology, $73,241-244$.

Mebius, R. E., \& Kraal, G. (2005). Structure and function of the spleen. Nature Reviews Immunology, 5, 606-616.

Mones, A. (1982). Estudios sobre la familia Hycrochoeridae (Rodentia) XIII. Parasitosis y patologías de Hydrochoerus Brisson, 1762. Revista de la Facultad de Humanidades y Ciencias de la Universidad de la República del Uruguay, 1, 297-329.

Morales, G. A., Wells E. A., \& Angel, D. (1976). The capybara (Hydrochoerus hydrochaeris) as a reservoir host for Trypanosoma evansi. Journal of Wildlife Diseases, 12, 572-574.

Moreira, J. R., Macdonald, D. W., \& Clarke, J. R. (1997). Correlates of testis mass in capybaras (Hydrochoerus hydrochaeris): dominance assurance or sperm production? Journal of Zoology, 241, 457-463.

Nunes, V. L. B., Oshiro, E. T., Dorval, M. E. C., Garcia, L. A. M., Da Silva, A. A. P., \& Bogliolo, A. R. (1993). Investigação epidemiológica sobre Trypanosoma (Trypanozoon) evansi no Pantanal Sul-Mato-Grossense. Estudio de reservatorios. Revista Brasileira de Parasitología, V, 41-44.

Ojasti, J. (1973). Estudio biológico del chigüire o capibara. FONAIAP, Caracas, Venezuela. $2^{\text {nd }}$ ed. 2011. Caracas: Editorial Equinoccio.

Pedersen, A. B., \& Greives, T. J. (2008). The interaction of parasites and resources cause crashes in a wild mouse population. Journal of Animal Ecology, 77, 370-377.

Penn, D., \& Potts, W. K. (1998). Chemical signals and parasite-mediated sexual selection. Trends in Ecology and Evolution, 13, 391-396.
Roberts, M. L., Buchanan, K. L., \& Evans, M. R. (2004). Testing the immunocompetence handicap hypothesis: a review of the evidence. Animal Behaviour, 68, 227-239.

Salas, V. (1999). Social organisation of capybaras in the Venezuelan Llanos (Ph.D. Thesis). Cambridge University, Cambridge, UK.

Salas, V., \& Herrera, E. A. (2004). Intestinal helminths of capybaras, Hydrochoerus hydrochaeris from Venezuela. Memórias do Instituto Oswaldo Cruz, 99, 563-566.

Sartori, C., \& Mantovani, R. (2013). Indirect genetic effects and the genetic bases of social dominance: evidence from cattle. Heredity, 110, 3-9.

Schulte-Hostedde, A. I., \& Elsasser, S. C. (2011). Spleen mass, body condition, and parasite load in male American mink (Neovison vison). Journal of Mammalogy, 92, 221-226.

Sokal, R. R., \& Rohlf, F. J. (1995). Biometry: the principles and practice of statistics in biological research. $3^{\text {rd }}$ ed. San Francisco, Ca. USA: W. H. Freeman.

Tejero, F., Arias-Mota, L .L., Roschman-González, A., Aso, P. M., \& Finol, H. J. (2010). Trypanosoma evansi: Ultrastructural Cardiac Muscle and Cardiac Microvasculature Changes in Experimental Murine Infections. Acta Scientiae Veterinariae, 38, 279-285.

Vicente, J., Pérez-Rodríguez, L., \& Gortázar, C. (2007). Sex, age, spleen size, and kidney fat of red deer relative to infection intensities of the lungworm Elaphostrongylus cervi. Naturwissenschaften, 94, 581-587.

Voigt, C. C., Behr, O., Caspers, B., Von Helversen, O., Knörnschild, M., Mayer, F., \& Nagy, M. (2008). Songs, scents, and senses: sexual selection in the greater sac-winged bat, Saccopteryx bilineata. Journal of Mammalogy, 89, 1401-1410.

Watkins, R. A., Moshier, S. E., Odell, W. D., \& Pinter, A. J. (1991). Splenomegaly and reticulocytosis caused by Babesia microti infections in natural populations of the montane vole, Microtus montanus. Journal of Protozoology, 38, 573-576.

Wilson, A. J., Morrissey, M. B., Adams, M. J., Walling, C. A., Guinness, F. E., Pemberton, J. M., Clutton-Brock, T. H., \& Kruuk, L. E. B. (2011). Indirect genetics effects and evolutionary constraint: an analysis of social dominance in red deer, Cervus elaphus. Journal of Evolutionary Biology, 24, 772-783.

Zahavi, A. (1975). Mate selection-a selection for a handicap. Journal of Theoretical Biology, 53, 205-214.

Zala, S. M., Potts, W. J., \& Penn, D. J. (2004). Scentmarking displays provide honest signals of health and infection. Trends in Ecology and Evolution, $15,338-344$. 
